\title{
Methodological Dialogue Between Christian Religious Education and Psychology
}

\author{
Noh Ibrahim Boiliu ${ }^{1}$, Evi Deliviana ${ }^{2}$, Maglon F. Banamtuan ${ }^{3}$, Donna \\ Sampaleng ${ }^{4}$, Harun Y. Natonis ${ }^{5}$
}

\begin{abstract}
${ }^{1}$ Christian Religious Education Department, Faculty of Teacher Training and Education, Universitas Kristen Indonesia, Jl. Mayjen Sutoyo No.2 Cawang, Jakarta Timur, Indonesia

${ }^{2}$ Departement of Guidance and Counselling, Faculty of Teacher Training and education, Universitas Kristen Indonesia, Jakarta, Indonesia

${ }^{3}$ Sekolah Tinggi Agama Kristen, Jl. Gn. Fatuleu, Oetete, Kota Kupang, Nusa Tenggara Timur, Indonesia

${ }^{4}$ Sekolah Tinggi Agama Kristen, Jl. Gn. Fatuleu, Oetete, Kota Kupang, Nusa Tenggara Timur, Indonesia

${ }^{5}$ Sekolah Tinggi Teologia IKAT, Jl. Rempoa Permai, RT.4/RW.11, Bintaro, Selatan Jakarta, Indonesia

boiliunoh@gmail.com, evi.deliviana@uki.ac.id, machonope@gmail.com, donnasampaleng@sttikat.ac.id, harunnatonis@gmail.com
\end{abstract}

\begin{abstract}
The purpose of this article is to reiterate that Christian Religious Education as one area of study of practical theology must establish dialogue or conversation with the science of developmental psychology. Christian education makes the assumption that change and growth are possible and desirable and, like all other education, require some understanding of the process of human development. Various attempts were made to utilize psychology in theological studies, especially practical theology which is operated in Christian religious education. The methodological assumptions that are built do not have to force theology away from its study.
\end{abstract}

\section{Keywords: Methodological Dialogue, Christian Religious Education, Psychology}

\section{INTRODUCTION}

Christian education is a suggestions term and implies there are at least two reference points that must be remembered and brought into the right relationship with each other. This is education and therefore involves elements that are naturally included in the consideration of the people being educated and what happens to them during the education process. This is Christianity and this fact gives a special orientation and new dimension. One can experience and set values in a certain way for looking at people, and about the goals of education which are always involved in Christian education and must be taken into account. Some points in Christian education is slightly different compared to other types of education. But at some point it becomes special. There is no adequate understanding of Christian education except the general element for all education that is recognized and identifies characteristics that distinguish Christian education from other education. Because Christian education is a service to people, like all other educations, Christian education must rely on some understanding of the nature of a personality. Whatever type of education is aimed at people and can achieve their goals is only significantly related to their interests, needs, and abilities.
To achieve the goals of Christian education are a have to build relationships of between other scientific disciplines. Christian education makes the assumption that change and growth are possible, desirable, and like all other educations, require some understanding of the process of human development. It's easy to find illustrations of religious school practices with the wrong concept of growth about how growth takes place.

Children are sometimes treated as if they are adults, with little consideration of changing needs and abilities from birth to adulthood, they sometimes think as if accumulation of only factual knowledge about the Bible and church doctrine is needed in Christian growth. Often group members are all treated equally, with little attention to the different problems of individuals arising from the different circumstances in which they live. Sometimes education is used as a tool of discipline, with a clear belief that bad children will be good. A good understanding of the principle of growth might help to avoid these mistakes. An adequate approach to the problem of human development must be based on an understanding of the learning process. Rapid progress has been made towards this understanding with scientific studies of human learning over the past half-century, mainly carried out by the psychologists, but increasingly 
recognized that such professional educators have an important bearing on their work. Educational psychology is now generally recognized as the foundation of knowledge that underlies educational practice. Therefore, the concept of learning must be broad enough to cover seemingly diverse aspects such as control over emotions, the development of motor skills, the function of perspective, the process of conceptualization and understanding. The ability to solve problems, and the acquisition of attitudes and ideals.

\section{METHOD}

This study was a preliminary research and did not intend to make a product of research i.e learning media or model of learning, but only did a conceptual approach prior to a research development. So, the main method carried out was to compare the various literature.

\section{DISCUSSION Dialogue Theology with Christian Religious Education}

As educators in Christian religious education, we must consciously hold Bible revelations and be under the word of God. And the word of God must be taught as God's wisdom. Because, in this way, believers are connected to the main source or authority to distinguish the Christian faith. This attitude implies that literalism is not without consideration but is the process of producing norms for mind and life through the interpretation of the truth of the Scriptures that are right and what it is. Scriptures are seen as divinely inspired and believers are called to find a biblical agenda in The Christian education (Pazmino, 2012).

Little in Pazmino (Pazmino, 2012), that the relationship between theology and Christian education is a crucial issue. Sara Little offers the following possibilities: 1) Theology is content that must be taught in Christian investigators; 2) Theology is a reference to what must be taught as well as to methodology and serves as the norm; for analyzing critical works and evaluating all Christian educations; 3) Theology is not relevant to the task of Christian education; 4) Because Christian education is autonomous. 5) "Doing theology" or theologizing is the education of Christ in the sense of enabling someone to reflect on their current experiences, and perspectives in the light of faith in Christian revelation. Christian theology and education are two different disciplines that are bound together and work together towards the Kingdom of God. Dialogue between theology and Christian education is not without challenges. He then recites little's thought that theological dialogue with Christian education presents another challenge (Pazmino, 2012). According to Groome (Groome, 2011), Christian educators can form reflections that characterize learning about God in theology. We can do this by asking essential questions like Groome's, namely: 1) what is the nature of Christian education? (Nature and purpose) 2) Why is Christian education important? (Aim) 3) where is Christian education holding? (Context) 4) how is Christian education running? (METHOD) 5) When is the right time to share Christian truth and experience? (Readiness) 6) who interacts with Christian education? (Relationship / relation)

By asking these six questions, Christian educators deal with theological issues in the areas of ecclesiology, soteriology, eschatology, anthropology, Christology, and doctrines about God, in the scriptures that influence education. Christian education is at its peak and an area of "practical theology." Just as Christian education can contribute to theological tasks, theology can also contribute to Christian education. Theology can be a tool for reflection on the mindset and practice of Christian education. Theology can also tell whether the practice of Christian education is carried out in accordance with the Bible by asking questions relating to the consistency of Bible values. A dialectical interaction between Christian theology and education, as different disciplines, can create interactions that then enables the actualization of Christian life according to the Bible, both in the church, and in the world. Therefore cooperative dialogue can increase the effectiveness and creative work of each of these disciplines.

In Pazmino's perspective, there must be a dialogical relationship between Christian education and theology. Christian education contributes to theological tasks and theology, on the other hand, contributes to the tasks of Christian education. Like Pazmino, Christian education exists on practical theology studies because it is an "applied" (theology). Apply theology department from pure theology (in my opinion and in terms of Aristotle as Theoria). Pure theology is called biblical theology (Vos, 1996), because in the study of Biblical theology, Biblical theologians have worked to provide materials (these materials are the results that are in every book with an interpretive approach) which will later will be used by systematic theologians (Enns, 2010) (in building doctrines) and practical theologians (both pastoral, missiological, Christian leadership, Christian religious education). In the context of practical theology and in the task of application, practical theology (even theology) must build relationships between other scientific disciplines outside theology.

In this context, for education, practical theology builds relationships with educational disciplines (in the 
future, education must build relationships with psychology, both education and developmental psychology. In my opinion, I understand the word education placed before the word Christian not see only as a term but a term of the context as independent scientific disciplines. This is the same when we refer to the terms Christian religious education sociology, Christian religious education psychology, Christian Religious Education Philosophy. Sociology, yes, sociology as scientific discipline, psychology, yes, psychology as a science, whereas the word Christian refers to activity as described by Groome (Groome, 2011), when we call it Christian education (religion), it will refer to the Christian word which reminds us that we have activities that are religious activities, in this context, activities".

This is where I say that the relationship is a relationship in terms of the method or approach, and not content. The content has been provided or supplied by theology while, "methods / approaches are supplied by psychology (Sadono, 2011). Here is my criticism to Pazmino that Pazmino did not make an in-depth explanation of the relationship, whether related to condition or unconditionally related. Pazmino only says there is a reciprocal relationship (Pazmino, 2012). Christian theology and education as disciplines can build interactions that enable the actualization of Christian life according to the Bible, both in the church, and in the world. Can increase the effectiveness and creative work of each of these disciplines. In the study of theology, and Christian religious education, humans become subjects of study in which by emphasizing humans as complex subjects of study The complexity of humanity (I would rather call it a dynamic being) can be seen as a problem, both in theology, and Christian religious educations that it will later related to the content of human studies, and the education of Christianity, humanity, and God, human beings and others. So, if humans and Christian religious education are to be studied in relation to humans and their God (theology), this study focuses on content or methods.

I reiterate that, the relationship between theology and education is in terms of methods not content. Education plays a role in the helping theology cross theological content related to "Christian religious activities (referring to Groome's explanation of Christianity as activity). Education provides a method (such as the analogy to Pazmino's explanation that views philosophy as a tool"). In this content too, Christian education practitioners and Christian educators must carefully use the work of biblical theologians in developing Christian education, so there is no theological bias at both the theoretical and practical levels.
Wise individuals that face problems soon realize that the two main approaches to human nature that is relevant to Christian education is often different: theological and psychological. People who read widely in these two fields will recognize there is a wide semantic gap between the two that has even hindered effective communication between specialists in two sections. On the other hand, theologians usually assume that they have the final answer revealed in some sacred literary body, institution or body and all need to do so to show the explicit meaning contained in divine revelation. Empirical research is not considered important. Some of them might even be considered as obstacles to the proper assessment of the truth about humans. Theologians realize there are very diverse interpretations of what is contained in revelation. But their energy is often expanded by arguments between themselves and efforts to gain acceptance of special facts by the forensic method. Little consideration has been made for direct observation or experimentation.

\section{Dialogue Theology with Psychology}

Wise individuals that face problems soon realize that the two main approaches to human nature that is relevant to Christian education is often different: theological and psychological. People who read widely in these two fields will recognize there is a wide semantic gap between the two that has even hindered effective communication between specialists in two sections. On the other hand, theologians usually assume that they have the final answer revealed in some sacred literary body, institution or body and all need to do so to show the explicit meaning contained in divine revelation. Empirical research is not considered important. Some of them might even be considered as obstacles to the proper assessment of the truth about humans. Theologians realize there are very diverse interpretations of what is contained in revelation. But their energy is often expanded by arguments between themselves and efforts to gain acceptance of special facts by the forensic method.

Little consideration has been made for direct observation or experimentation. Psychologists on the other hand, in their efforts to reach their scientific discipline, have abandoned their tasks as though little wisdom is contained in ancient, sacred, or otherwise documents, and as if valid knowledge depends only on laboratory experiments. Each individual or group is forced to work to prohibit boundaries, psychologists also tend to become sectarian, as experiments have added new insights about limited aspects of the whole of human nature, proponents of several, "schools" tend to voice their generalizations to philosophy, ignore or even denounce peer findings those who deal with other aspects 
or work with different tools. With a fairly intense struggle with various theological systems, and many schools of psychology, there is little time or opportunity to communicate about the gap that exists between the two disciplines.

In general, psychologists have paid little attention to theological discussion; and conversely, theologians have not paid more attention to the results of psychological investigations. However, because they both pay attention and relate to humans, it is possible for their fields of activity to coexist and be expected to overlap; then the psychologist and theologian must be able to establish effective communication must be clear so that every wise reader will test the literature (Pazmino, Robert, 2012); (Little, Lawrence, 1962).

\section{Dialogue Psychology with Christian Religious Education}

About psychology at the study of Christian Religious Education. What is the importance of developmental psychology at Christian Religious Education? This question can be self-criticizing for implementing Christian Religious Education. It can also be a kind of rejection because often "tensions arise due to the lack of awareness of the nature of theology" (Sandage, 2015) which forms the basis of Christian Religious Education studies with psychology as an operational social discipline. In response, it is also important to refer to Groome's response to the religious education of Ronald Goldman and others. In connection with this tension, Groome sees that educators must be careful when they begin to take insights from developmental psychology research. What is stated as a descriptive thing cannot be accepted as a prescriptive thing, just like what is, "what really exists, never automatically accepted as what "should be" (Groome, 2011). Religious education also should not be a "courier" of expert's developmental psychology, we must bring our issues, questions, understandings, and languages, otherwise our activities will become operational models of social science, and our efforts will be reduced to techniques. On the other hand, ignoring the meetings of developmental psychologists is a carelessness (Groome, 2011).

Iris V. Cully added that, "the results of new psychological research, suggest the possibility of inner impulses for moral practitioners (Cully, 2019) to pay attention to Christian Religious Education and developmental psychology critically so there is no deviation regarding content. Looking at the importance of developmental psychology, the fundamental things that occur to Christian Religious Education with regard to "the inseparability of educational values "and the values "of socialization. Christian Religious Education places development psychology as a discipline needed in developing approaches to teaching and learning Christian Religious Education" (Hadinoto, 2012; Evans, 2013). Groome sees that what is new to our time is the increasing amount of research conducted on various aspects of human development (Groome, 2011). Among the well-known developmental psychologists, those who have a special attraction for educators are Piaget (cognitive development), Kohlberg (moral development), Fowler (faith development), Loevinger (ego development), and Selman (empathy development) (Hadinoto, 2012; Groome, 2011; Pazmino, 2012; Supratiknya, 1995; Lownsdale, 1997).

Their research is continuous and their findings must be seen as helpful indicators not as complete and final descriptions. Groome designed several problems of with education that was laden with effort involves/involved psychological approaches.

In discussing the psychological relationship, and Christianity, there are principles which at an early stage can be observed from Groome's thought. He argues that, "Christian theology, in the most technical and precise sense, is a field of study that connects the understanding of the meaning of God in our lives based on a systematic and thorough investigation of both the Christian faith tradition, and the living experiences of people" (Groome, 2011; Greenway et al, 2018; Helminiak, 2009). Theology deals with how to build a human being to recognize his true self and act from the true perspective of God's Word, and psychology plays a role in seeking the right approach for each human being's existence and needs regarding the reality of his unique individuality (Watts, 2010). For example, Michael E. McCullough, said that "many religions and value systems assume that forgiveness is a source of human strength, producing interpersonal, mental, or physical benefits. This assumption can be transformed into a scientific hypothesis (McCullough, 2000). McCullough's conclusion provides an example of in this perspective, Lakatos proposes to look for a relationship between psychology and theology that the two share in a rational structure (Dueck \& Lee, 2005). According to Pazmino (Pazmino, 2012), combining the views of Christian Education with psychology is important for several reasons.

Based on the presentation above, in theology (practice) and psychology studies (Strawn, 2019), especially regarding practice, can pay attention to each discipline with understandings about individuals in this case the perpetrators of behavior both educators and students who become educational the target. Based on Brock's approach, there are several behaviors he listed as 
an effort to see what contact is built from the relationship between theology and psychology.

Integrating the views of Christian education with psychology is a challenge. According to Pazmino (Pazmino, 2012), it was caused by several reasons. First, education that is generally understood and practiced during the 21 st century is very dependent on psychology, and its various theories, research findings and practices. This happens because psychology as a scientific discipline has included studies of the subconscious and human behavior in the learning process.

Education is closely related to humans, and the teaching-learning process so that educators can obtain many things by considering the results of psychological research. Second, there are various branches of psychology, including behavioral psychology, psychoanalytic, cognitive, developmental, gestate, humanistic, social, and transformation. With a variety of different perspectives, issues that often arise, such as in educational psychology, are branches of psychology, whether they have been merged or integrated, which consists of the best ingredients in understanding humans, and the way humans operate in their lives. The first approach can be described as the differentiation or fragmentation approached. The first approach is a separate, but equal approach.

The second approach rejects knowledge from psychology and places humans in predetermined religious contexts, where human life is totally shaped by religious knowledge and perspectives that are not painted by psychology or by knowledge of self-development. This approach maintains there is nothing else, except the Bible or religious understanding that determines life and lead to a heteronomies attitude in life. The third approach can be explained as an integrated approach, but the potential for misdirection. It is a total psychological approach to Christian education and the development of faith that reshapes radical faith demands and reduces the unique features of Christian theology (Strawn, 2019), such as grace, salvation, sin and guilt, and personal response to faith. The fourth and final approach is an integrated and directed approach in relation to religious values. This approach requires openness and careful evaluation of Christian educators to assess the assumptions, and goals of their theological and psychological views (Strawn, 2019).

Various attempts were made to utilize the psychology at theological studies, especially practical theology which is operated in Christian religious education. However, methodological assumptions that are built do not have to force theology away from its studies. Strawn also revealed that the "conversation" of theology and psychology is currently limited by a series of difficulties that seem difficult to overcome, ranging from competing methodological commitments to assumptions about theological projects that are not susceptible to empirical verification or falsehood. Comprehensive experimental theology has the capacity to move beyond the paradigm of conversation with ways that the current approach cannot, especially because it involves an interdisciplinary understanding of what it means to be human. This shows that experimental theology or Experimental Theology (ET) understands, "conversation" only as a starting point for interdisciplinary projects, theological reasons empirically, and advance psychological and theological research (Strawn, 2019).

\section{CONCLUSIONS}

Christian theology and education must be in a deep and intense relationship. For theology must contribute or supply content with Christian education while Christian education contributes to the practical tasks of theology. Theology must be a mindset of reflection tools for the practice of Christian education, helping to tell whether Christian education practices are carried out in accordance with the Bible by asking questions relating to the consistency of Bible values. The dialectical interaction between Christian theology and education enables the actualization of the Christian life according to the Bible.

Cooperative dialogue can increase the effectiveness and creative work of each of these disciplines. In the context of practical theology and in the task of application, practical theology (even "theology") must build relationships between other scientific disciplines outside theology. In this context, for education, practical theology builds relationships with educational disciplines (in the future, education must build relationships with psychology, both educational psychology and developmental psychology.

Christian religious education and psychology, both care for one another and relate to humans. Similarity in formal study objects of these two disciplines allows their fields of activity to coexist and be expected not to overlap but to dialogue in terms of methodology Psychologists, theologians, Christian religion teachers and practitioners of Christian religious education must be able to establish effective communication to break down the methodological gap So that it utilizes psychology of theological studies especially practical theology which is operated in Christian religious education With notes, the methodological assumptions that are built do not have to force theology away from its studies. 


\section{REFERENCES}

[1] Cully, I. V., 2019. Dinamika Pendidikan Kristen.BPK Gunung Mulia, Jakarta.

[2] Dueck, A., Lee, C., 2005. Why Psychology Needs Theology: A Radical Reformation-Perspective. Eerdmans Publishing, Grand Rapids.

[3] Enns, P., 2010. The Moody Hand Book Of Theology. Moody Press, Chicago.

[4] Evans, S. C., 2013. Towards The Possible Integration Of Psychology And Christian Faith: Faculties Of Human Personality And The Lordship Of Christ, 1-8. Https://Doi.Org/Doi. Org/10.4102/Ids.V50i1.1908

[5] Greenway, T. S., Schnitker, S. A., Shepherd, A. M., Greenway, T. S., Schnitker, S. A., Can, A. M. S., ... Shepherd, A. M., 2018. The International Journal For The Psychology Of Religion Can Prayer Increase Charitable Giving? Examining The Effects Of Intercessory Prayer , Moral Intuitions , And Theological Orientation On Generous Behavior Can Prayer Increase Charitable Giving? Exa. The International Journal For The Psychology Of Religion, 28(1), 3-18. Https://Doi.Org/10.1080/10508619.2017.1406790

[6] Groome, T. H., 2011. Pendidikan Agama Kristen: Berbagi Cerita Dan Visi Kita. BPK Gunung Mulia, Jakarta.

[7] Hadinoto, N. K. A., 2012. Dialog Dan Edukasi: Keluarga Kristen Dalam Masyarakat Indonesia (6th Ed.). BPK Gunung Mulia, Jakarta.

[8] Helminiak, D. A., 2009. International Journal For The Psychology Of Religion A Scientific Spirituality: The Interface Of Psychology And Theology, (July 2012), 37-41.

Https://Doi.Org/Dx.Doi.Org/10.1207/S15327582ijpr0 601_1

[9] Little, Lawrence, C., 1962. Foundations For A Philosophy Of Christian Education. Abingdon Press, New York.

[10] Lownsdale, S., 1997. Faith Development Across The Life Span: Fowler's Integrative Work, 25(1), 49-63. Https://Doi.Org/Doi.Org/10.1177/0091647197025001 05

[11] Mccullough, M. E., 2000. Forgiveness As Human Strength : Theory, Measurement, And Links To WellBeing, 1(1), 43-55.

[12] Pazmino, Robert, W., 2012 Fondasi Pendidikan Kristen (1st Ed.). STT Bandung-BPK Gunung Mulia.

[13] Sadono, S., 2011. Psikologi Pendidikan Agama Kristen. Sekolah Tinggi Teologia Baptis, Semarang.

[14] Sandage, S. B., Brown, J. K., 2015. Relational Integration, Part I: Differentiated Relationality Between Psychology And Theology, (2000). Https://Doi.Org/10.1177/009164711504300302

[15] Strawn, B., 2019. Experimental Theology: Theological Anthropology And The Psychological Sciences. Https://Doi.Org/10.1177/0091647119854117

[16] Supratiknya, A., 1995. Teori Perkembangan Kepercayaan: Karya-Karya Penting James Fowler.
Kanisius, Yogyakarta.

[17] Vos, G., 1996. Biblical Theology: Old And New Testaments. Eermands Publishing, Pennsylvania.

[18] Watts, F., 2010. Doing Theology In Dialogue With Psychology.

Https://Doi.Org/10.1177/009164711204000109 